\title{
POSTĘPOWANIE ODWOŁAWCZE W PROCESIE KARNYM NA GRUNCIE NOWELIZACJI Z DNIA 19 LIPCA 2019 R. - ZAGADNIENIA WYBRANE
}

\section{Wstęp}

Ustawą z dnia 19 lipca 2019 r. o zmianie ustawy - Kodeks postępowania karnego oraz niektórych innych ustaw ${ }^{1}$ ustawodawca przeprowadził gruntowną zmianę polskiego procesu karnego, której celem była m.in. chęć usprawnienia postępowań, dostosowanie ich do „wyzwań wynikających z rozwoju technologicznego" oraz rezygnacja ze zbędnego - zdaniem projektodawców - formalizmu, jak również wprowadzenie ułatwień dla uczestników postępowania i zapobieżenie obstrukcji procesowej stron².

Przedmiotem tej pracy są przepisy zamieszczone w dziale IX K.p.k. ${ }^{3}$. Z uwagi na ograniczenia redakcyjne oraz niewątpliwą obszerność wskazanej nowelizacji, dalszej analizie nie zostaną poddane wszystkie, ale wyłącznie niektóre z przeprowadzonych zmian, tj. te, które uznano za najbardziej problematyczne, a równocześnie kluczowe. Większość z nich z pewnością zasługuje na odrębne i zdecydowanie bardziej szczegółowe omówienie, w związku z czym w toku dalszych wywodów siłą rzeczy

* Doktorant, Uniwersytet Wrocławski; e-mail: bartosz.lukowiak@uwr.edu.pl, https:/ / orcid.org/0000-0003-3993-2182.

1 Dz. U. poz. 1694.

2 Uzasadnienie rzadowego projektu ustawy o zmianie ustawy - Kodeks postępowania karnego oraz niektórych innych ustaw (druk nr 3251/VIII kadencja), http:/ /orka.sejm.gov.pl/Druki8ka.nsf/ 0/A617BC771FDAE095C12583AC004875E9/\%24File/3251.pdf, s. 1 [dostęp: 23.07.2019 r.].

3 Ustawa z dnia 6 czerwca 1997 r. - Kodeks postępowania karnego (Dz. U. z 2018 r. poz. 1987 z późn. zm.) (dalej: K.p.k.). 
ograniczono się jedynie do ich pobieżnej analizy, skoncentrowanej wokół najistotniejszych kwestii.

\section{Zarzut nieprzeprowadzenia dowodu $\mathrm{z}$ urzędu}

W nowowprowadzonym art. 427 § 3 a in principio K.p.k. prawodawca ustanowił zakaz powoływania się w treści środka odwoławczego na zarzut nieprzeprowadzenia dowodu z urzędu, którego celem ma być wzmocnienie elementów kontradyktoryjności. W uzasadnieniu projektu nowelizacji wskazano, że

Bez wprowadzenia tego unormowania strona mogłaby przed sądem a quo wykazywać całkowitą bierność, jeżeli chodzi o inicjatywę dowodową, a w razie niekorzystnego dla siebie rozstrzygnięcia zarzucać taką bierność sądowi przez nieprzeprowadzenie stosownego dowodu z urzędu ${ }^{4}$.

Podobne rozwiązanie funkcjonowało w polskim procesie karnym w okresie od 1 lipca 2015 r. do 14 kwietnia 2016 (por. nieobowiązujący już art. 427 § 4 K.p.k.), z tym że było ono dostosowane do ówczesnego brzmienia art. 167 K.p.k., w myśl którego przeprowadzenie dowodu przez sąd z urzędu miało być absolutnym wyjątkiem. W 2016 r. zdecydowano się na powrót do rozwiązań hołdujących zasadzie inkwizycyjności, w związku z czym konsekwentnie umożliwiono stronom podnoszenie również i tego zarzutu.

Tymczasem de lege lata prawodawca niejako "stanął w rozkroku”. Z jednej strony z każdą kolejną reformą niewątpliwie wzmacnia elementy inkwizycyjności w postępowaniu pierwszoinstancyjnym, a z drugiej kładzie coraz mocniejszy nacisk na pierwiastek kontradyktoryjny w postępowaniu odwoławczym. Z jednej strony nie wprowadza żadnej zmiany w treści art. 167 K.p.k., a z drugiej - niejako „tylnymi drzwiami” - kieruje do stron wyrażoną $w$ art. 427 § 3a in principio K.p.k. dyrektywę o treści „podejmuj inicjatywę dowodową przed sądem I instancji, albowiem w przeciwnym wypadku nie będziesz mógł kwestionować bierności tego sądu na późniejszym etapie postępowania".

4 Uzasadnienie..., s. 53, zob. również D. Świecki, Konstrukcja apelacji jako środka odwoławczego w procesie karnym, Warszawa 2018, s. 262. 
Rozwiązanie to, właśnie $\mathrm{z}$ uwagi na jego umiejscowienie jedynie $\mathrm{w}$ przepisach dotyczących postępowania odwoławczego, w praktyce może okazać się nieczytelne. Wydaje się, że adresat takiej normy powinien być pouczony o fakcie jej obowiązywania już na etapie postępowania pierwszoinstancyjnego (a nie dopiero na etapie konstruowania apelacji czy zażalenia), podczas gdy aktualne brzmienie art. 167 K.p.k. jawi się w tym zakresie jako co najmniej mylące, sugerując, iż odpowiedzialność za prawidłowe ustalenie stanu faktycznego spoczywa w równej mierze na stronach, jak i na sądzie. Obecnie jedynie częściowo rolę takiego „pouczenia" może pełnić art. 170 § 1 pkt 5 K.p.k. (również dodany na mocy nowelizacji z 19 lipca 2019 r.), nakazujący oddalić wniosek dowodowy zgłoszony po zakreślonym przez organ procesowy i znanym stronie terminie. Warto jednak odnotować, że wyrażona w tym przepisie norma dotyczy zupełnie innej kwestii, tj. granic temporalnych podejmowania inicjatywy dowodowej przez strony, a nie negatywnych konsekwencji związanych $\mathrm{z}$ rezygnacją $\mathrm{z}$ tego uprawnienia, $\mathrm{w}$ dodatku skierowana jest nie do stron, ale wyłącznie do organu procesowego, albowiem to do jego obowiązków należy podejmowanie decyzji w przedmiocie dopuszczenia zawnioskowanego dowodu 5 .

Należy zauważyć, że omawiana norma, pomimo jej prekluzyjnego charakteru, nie zdjęła z sądu ad quem wynikającego z art. 2 § 2 i art. 366 $\S 1$ in fine $\mathrm{w}$ zW. $\mathrm{z}$ art. 458 K.p.k. obowiązku dochodzenia do prawdy materialnej poprzez wyjaśnianie wszystkich istotnych okoliczności sprawy, przez co zamierzone wzmocnienie kontradyktoryjności $\mathrm{w}$ istocie okazuje się być jedynie pozorne ${ }^{6}$.

Niewątpliwą wadą analizowanego rozwiązania jest również jego szeroki zakres zastosowania, który - inaczej niż dawny art. 427 $\S 4$ K.p.k. - nie ogranicza się wyłącznie do postępowania sądowego, ale zgodnie z art. 465-467 K.p.k. obejmuje również zażalenia na postanowienia

5 Być może zatem należałoby rozważyć wprowadzenie również normy kompetencyjnej zezwalającej organom procesowym na zakreślanie terminów, w których możliwe jest składanie wniosków dowodowych, a nie poprzestawać na milczącym uznaniu, że norma taka wynika instrumentalnie z samego faktu obowiązywania normy dotyczącej skutków zawnioskowania dowodu po upływie tego terminu.

6 Na temat relacji pomiędzy obowiązywaniem zasady prawdy materialnej w postępowaniu odwoławczym a regulacjami o charakterze prekluzyjnym zob. M. Fingas, Orzekanie reformatoryjne w instancji odwotawczej w polskim procesie karnym, Warszawa 2016, s. 104 i nast. 
i zarządzenia organów postępowania przygotowawczego, a nawet na ich czynności i zaniechania. $Z$ uwagi na specyfikę postępowania przygotowawczego (zwłaszcza jego inkwizycyjny charakter oraz związany z tym deficyt informacji po stronie podejrzanego i pokrzywdzonego), aktywny udział stron, w tym również składanie skutecznych wniosków dowodowych, jest w jego toku znacząco ograniczony, przez co niełatwo zrozumieć decyzję o pozbawieniu ich możliwości wytknięcia organowi ścigania - np. w treści zażalenia na postanowienie o umorzeniu postępowania przygotowawczego - niedostatecznego korzystania z przysługującej mu inicjatywy dowodowej.

Z uwagi na wskazane podobieństwo komentowanego unormowania do uchylonego art. 427 § 4 K.p.k. należy uznać, że przynajmniej część poglądów wyrażonych na tle tego ostatniego niejako odzyskała przymiot aktualności, w związku z czym mutatis mutandis można je odnieść do art. 427 § 3a in principio K.p.k. Jednym $z$ nich jest niewątpliwie trafne spostrzeżenie, zgodnie z którym jeżeli strona podniosła w skardze odwoławczej wyłącznie zarzut nieprzeprowadzenia dowodu ex officio, prezes sądu I instancji powinien odmówić przyjęcia takiego środka w trybie art. 429 $\S 1$ K.p.k. z uwagi na jego niedopuszczalność z mocy prawa ${ }^{7}$ (wszak nie może być dopuszczalny środek oparty wyłącznie na zarzutach niedopuszczalnych). Obecnie chodziłoby tu rzecz jasna jedynie o sytuacje, w których zarzut nieprzeprowadzenia dowodu z urzędu nie dotyczy okoliczności expressis verbis wskazanych w treści komentowanego przepisu, w odniesieniu do których jego podnoszenie jest przecież w dalszym ciągu dopuszczalne.

Dla pełnego zrozumienia omawianej normy konieczne jest przeanalizowanie wyjątków wskazanych w art. 427 § 3a in fine K.p.k., których zaskakująca wręcz pojemność treściowa prowadzi do wniosku, że w praktyce wstępna część tej regulacji jest co najwyżej wyjątkiem od reguły. Są one jednak zbieżne $\mathrm{z}$ wyjątkami od omawianej w dalszej części tekstu podstawy oddalenia wniosku dowodowego, o której mowa w art. 452 $\S 2$ pkt 2 K.p.k., w związku z czym ich analizę również w tym miejscu należy uznać za niecelową (zob. pkt 4).

7 Tak J. Matras, w: Kodeks postepowania karnego. Komentarz, red. K. Dudka, Warszawa 2018, teza 12 do art. 427. 


\section{Zarzut obrazy przepisów prawa materialnego}

Jedną z najbardziej interesujących zmian jest zreformowanie podstaw odwoławczych poprzez rozdzielenie dotychczasowej przesłanki naruszenia prawa materialnego na dwie odrębne podstawy, a mianowicie na obrazę przepisów tego prawa w zakresie kwalifikacji prawnej czynu (art. 438 pkt 1 K.p.k.) oraz na każdą inną obrazę przepisów prawa materialnego, ",chyba że pomimo błędnej podstawy prawnej orzeczenie odpowiada prawu" (art. 438 pkt 1a K.p.k.). Ratio legis wskazanego rozwiązania polegało na umożliwieniu zmiany lub uchylenia zaskarżonego orzeczenia jedynie wtedy, gdy strona wykazała wpływ takiego naruszenia na treść orzeczenia ${ }^{8}$.

Pomijając fakt, iż orzeczenie dotknięte obrazą przepisów prawa nie może równocześnie odpowiadać prawu (contradictio in adiecto), nie sposób nie dostrzec, że ustawodawca wykazał się w tym przypadku rażącym niezrozumieniem istoty norm z zakresu prawa materialnego. Wszak ich naruszenie zawsze - w mniejszym bądź większym stopniu - wpływa na treść orzeczenia, choćby nawet nie dotyczyło kwalifikacji prawnej czynu. Jest tak m.in. dlatego, że rozstrzygnięcia oparte na tychże normach zawarte są już w jego treści (arg. ex art. $94 \S 1$ pkt 4 oraz art. 413 $\S 1$ pkt 6 i $\$ 2$ pkt 2 K.p.k.), a zatem - inaczej niż w odniesieniu do podstaw wskazanych w art. 438 pkt 2-4 K.p.k. - nie trzeba ich wywodzić w przeważającej mierze z treści uzasadnienia9 9

Wydaje się, że wbrew początkowym zamysłom projektodawców ciężar udowodnienia wpływu takiego naruszenia na treść orzeczenia ostatecznie nie będzie spoczywał na skarżącym. Wskazuje na to w pierwszej kolejności dokonana $\mathrm{w}$ toku prac parlamentarnych zmiana pierwotnego brzmienia art. 438 pkt 1a in fine K.p.k. (,,jeżeli mogła ona mieć wpływ na treść orzeczenia”) na aktualne („chyba że pomimo błędnej podstawy prawnej orzeczenie odpowiada prawu" $)^{10}$. Z posłużenia się zwrotem

8 Uzasadnienie..., s. 58.

9 Tak również D. Świecki, którego zdaniem „[...] w wypadku obrazy prawa materialnego [...] taki [tj. dotyczący wykazania wpływu uchybienia na treść orzeczenia - B.Ł.] wymóg jest zbędny, ponieważ naruszenie przepisów prawa materialnego, które stanowi podstawę wydanego wyroku, powoduje, że orzeczenie jest wadliwe, więc zawsze takie uchybienie ma wpływ na jego treść" (D. Świecki, Konstrukcja..., s. 86).

10 Zob. zapis przebiegu posiedzenia Komisji Nadzwyczajnej do spraw zmian w kodyfikacjach nr 73 z dnia 2 lipca 2019 r., http:/ / orka.sejm.gov.pl/Zapisy8.nsf/0/E00A2C18E6 132A5EC125843B004737A6/ \$file/0446608.pdf, s. 26 [dostęp: 24.07.2019 r.]. 
„chyba że” należy wyprowadzić określone konsekwencje w zakresie ciężaru dowodzenia.

Na gruncie prawa cywilnego wyrażono pogląd, zgodnie z którym

niektóre przepisy prawne posługujące się zwrotem „chyba że” - wprowadzają [...] odstępstwo od reguły ogólnej [tj. od reguły ei incumbit probatio qui dicit non qui negat - B.Ł.], które polega na tym, że niektóre elementy hipotezy normy prawnej nie wymagają udowodnienia, a adresat tej normy musi wykazać przeciwieństwo, udowodnić, że dany fakt objęty hipotezą normy nie zaistniał ${ }^{11}$.

Co prawda w piśmiennictwie karnistycznym jak dotąd nie poświęcono uwagi analizie znaczenia tego konkretnego zwrotu, jednakże nie powinno budzić żadnych wątpliwości, że opisana konstrukcja bywa używana również na gruncie prawa karnego (np. w art. 45 § 3 Kodeksu karnego ${ }^{12}$ ).

Przekładając powyższe rozważania na grunt komentowanej regulacji, warto w pierwszym rzędzie ustalić jej adresata. Choć przepis art. 438 K.p.k. dość powszechnie kojarzony jest z unormowaniem wskazującym na zarzuty możliwe do podniesienia w treści środka odwoławczego, to jednak z normatywnego punktu widzenia wyłącznym adresatem zakodowanej w nim normy nie jest skarżący, ale organ rozpoznający wniesioną przez niego skargę, na co wskazuje posłużenie się przez ustawodawcę formułą „orzeczenie ulega uchyleniu lub zmianie w razie stwierdzenia: [...]"13. Wyrażenie to warto zestawić chociażby z omówionym wcześniej art. 427 § 3a K.p.k., który niewątpliwie został zaadresowany do samych skarżących („nie można podnosić zarzutu”).

W dalszej kolejności należy się odnieść do zagadnienia treści domniemania wyrażonego w art. 438 pkt 1a K.p.k. Domniemania prawne zawierają $\mathrm{w}$ sobie nakaz przyjęcia, iż pewien fakt miał miejsce,

11 P. Machnikowski, w: Kodeks cywilny. Komentarz, red. E. Gniewek, Warszawa 2006, s. 24. Autor wprawdzie zastrzega, że z teoretycznego punktu widzenia przepisy te są jedynie "podobne w skutkach ich zastosowania do domniemań prawnych", jednocześnie nimi nie będąc, jednakże problem ten nie ma w tym miejscu większego znaczenia.

12 Ustawa z dnia 6 czerwca 1997 r. - Kodeks karny (Dz. U. z 2018 r. poz. 1600 z późn. zm.).

13 Tak też D. Świecki: „[...] w Kodeksie postępowania karnego nie ma odrębnie wskazanych i opisanych przesłanek (podstaw) zarzutów odwoławczych. Natomiast art. 438 i 439 k.p.k., które są adresowane do sądu odwoławczego, zawierają przyczyny uchylenia lub zmiany orzeczenia [...]" (D. Świecki, Konstrukcja a s. 83-84), zob. jednak art. 447 § 5 K.p.k., w którym mowa jest o „zarzutach określonych w art. 438 pkt 3 i 4”. 
jeżeli wystąpił inny fakt ${ }^{14}$. Stosując ten wypracowany w prawoznawstwie schemat rozumowania na potrzeby omawianej regulacji, należy przyjąć, że przesłankę domniemania stanowi tu stwierdzenie naruszenia prawa materialnego, jego wnioskiem zaś jest wpływ tego naruszenia na treść orzeczenia. Tym samym na gruncie analizowanej podstawy odwoławczej ciężar dowodu rozkłada się w specyficzny, nieznany żadnej z pozostałych przesłanek sposób. Skarżący obowiązany jest - pod rygorem upadku jego twierdzenia - udowodnić naruszenie przez sąd I instancji określonych przepisów prawa materialnego, podczas gdy sąd odwoławczy obowiązany jest:

1) albo zastosować się do omówionego domniemania i przyjąć za udowodnione, że wykazane przez skarżącego naruszenie miało wpływ na treść orzeczenia;

2) albo też wykazać, że - pomimo błędnej podstawy prawnej - orzeczenie odpowiada prawu.

Warto jednak podkreślić, że poczynione wyżej ustalenia dotyczą wyłącznie ciężaru dowodu w znaczeniu materialnym ${ }^{15}$, w związku czym w konkretnej sprawie ciężar dowodzenia ${ }^{16}$ braku wpływu wykazanego naruszenia na prawidłowość orzeczenia będzie spoczywał również na stronie, która orzeczenia nie skarżyła i której zależy na jego utrzymaniu w mocy (np. na obrońcy w razie wniesienia przez oskarżyciela publicznego apelacji na niekorzyść oskarżonego).

Przemawia za tym również porównanie poszczególnych funktorów użytych w art. 438 K.p.k. W pkt 2 i 3 tego przepisu ustawodawca posłużył się zwrotem "jeżeli”, rozumianym jako "tylko wtedy, gdy”, podczas gdy w pkt 1a użyto wyrażenia "chyba że”. Zgodnie z powszechnie przyjmowanym zakazem wykładni synonimicznej, wspartym dogmatem o racjonalności ustawodawcy, nie można nadawać różnym zwrotom - w tym zwłaszcza użytym w obrębie tej samej jednostki redakcyjnej danego aktu

14 A. Bator, w: Wrowadzenie do nauk prawnych. Leksykon tematyczny, red. A Bator, Warszawa 2008, s. 183.

15 Zob. J. Skorupka, w: Proces karny, red. J. Skorupka, Warszawa 2018, s. 203; szerzej M. Cieślak, Polska procedura karna. Podstawowe założenia teoretyczne, Warszawa 1973, s. 165.

${ }^{16}$ W tej pracy zamiennie użyto pojęć „ciężar dowodu” i „ciężar dowodzenia”, mimo że w doktrynie przyjmuje się ich treściową odmienność; por. J. Skorupka, w: Ciężar dowodu i obowiązek dowodzenia w procesie karnym, red. W. Jasiński, J. Skorupka, Warszawa 2017, s. 12, którego zdaniem drugi z podanych zwrotów oznacza „powinność dowodzenia nie ze względu na swój interes, ale za (sic!) względu na cudzy interes (klienta, państwa)". 
prawnego - tego samego znaczenia ${ }^{17}$. Oznacza to, że w odmiennym sposobie zredagowania jednej z tych podstaw należy doszukiwać się powodów dla ich odmiennego rozumienia. W przeciwnym wypadku ustawodawca pozostałby przecież przy pierwotnie projektowanym brzmieniu wskazanego przepisu albo też wyraziłby tę podstawę od strony pozytywnej (np. „Orzeczenie ulega uchyleniu lub zmianie w razie stwierdzenia obrazy przepisów prawa materialnego w innym wypadku niż wskazany w pkt 1, jeżeli orzeczenie nie odpowiada prawu" $)^{18}$.

Argumentu na rzecz nieobciążania skarżącego ciężarem udowodnienia wpływu naruszenia prawa materialnego na treść orzeczenia dostarczają także wyniki wykładni funkcjonalnej. Jak już była o tym mowa, naruszenie norm prawnomaterialnych ma ze swej istoty zawsze albo, przyjmując na moment optykę projektodawcy, prawie zawsze wpływ na treść orzeczenia, w związku z czym nie sposób przekonująco uzasadnić, dlaczego racjonalny ustawodawca miałby nakładać na strony obowiązek dowodzenia np. tego, że wymierzenie oskarżonemu kary dożywotniego pozbawienia wolności za dokonanie przestępstwa znieważenia (co przecież nie jest przypadkiem obrazy przepisów prawa materialnego w zakresie kwalifikacji prawnej czynu, a równocześnie nie stanowi bezwzględnej przesłanki odwoławczej ${ }^{19}$ ) miało wpływ na treść zaskarżonego orzeczenia, zwłaszcza że jednym z celów nowelizacji było wprowadzenie ułatwień dla uczestników postępowania.

Co więcej, przyjęcie odmiennego stanowiska prowadziłoby do naruszenia wewnętrznej spójności regulacji dotyczącej podstaw odwoławczych. Przykładowo, skarżący, któremu za dokonanie przestępstwa znieważenia wymierzono karę ograniczenia wolności, kwestionujący rażącą niewspółmierność tej kary (art. 438 pkt 4 K.p.k.) z uwagi na fakt, że wystarczające byłoby wymierzenie mu kary grzywny, nie musiałby

17 R.A. Stefański, Wykładnia przepisów prawa karnego, w: Źódła prawa karnego, red. T. Bojarski, Warszawa 2011, s. 498.

18 Właśnie od strony pozytywnej (tj. z użyciem zwrotu ,jeżeli”, a nie „chyba że” ) przesłankę tę ujęto na gruncie postępowania sądowoadministracyjnego, które - jak wynika z analizy przebiegu posiedzenia właściwej komisji sejmowej - stanowiło wzór dla wprowadzenia omawianej podstawy odwoławczej; por. art. 184 ustawy z dnia 30 sierpnia 2002 r. Prawo o postępowaniu przed sądami administracyjnymi (Dz. U. z 2018 r. poz. 1302 z późn. zm.), zgodnie z którym „Naczelny Sąd Administracyjny oddala skargę kasacyjną, jeżeli [...] zaskarżone orzeczenie mimo błędnego uzasadnienia odpowiada prawu".

19 Zob. wyrok SN z dnia 14 lutego 2007 r., III KK 3/07, OSNwSK 2007, nr 1, poz. 418. 
udowodniać wpływu tej niewspółmierności na treść orzeczenia (również zresztą oczywistego). Równocześnie ten sam skarżący, któremu za to samo przestępstwo wymierzono z kolei karę 25 lat pozbawienia wolności, zarzucający orzeczeniu obrazę prawa materialnego niebędącą naruszeniem w zakresie kwalifikacji prawnej czynu (art. 438 pkt 1a K.p.k.), a zatem zdecydowanie bardziej rażące uchybienie, byłby zmuszony udowodnić nie tylko sam fakt naruszenia, ale i jego hipotetyczny wpływ na treść orzeczenia.

Należy przyjąć, że skoro strona nie musi udowadniać takiego wpływu w przypadku mniejszej dysproporcji pomiędzy karą wymierzoną a karą słuszną (pomiędzy karą ograniczenia wolności a karą grzywny), to a minori ad maius nie musi tego robić również w odniesieniu do zdecydowanie większej dysproporcji tego typu (pomiędzy karą 25 lat pozbawienia wolności a karą grzywny).

\section{Zaskarżenie uzasadnienia orzeczenia}

Kolejną z istotnych zmian jest uchylenie art. 437 § 1 zd. 2 K.p.k. i wprowadzenie art. 443a K.p.k., który w założeniu projektodawców ma w sposób kompleksowy regulować kwestię zaskarżania samego uzasadnienia orzeczenia. Wydaje się, że rozwiązanie to należy ocenić pozytywnie co najmniej z dwóch powodów.

Po pierwsze, jak wynika z analizy dotychczasowego dorobku doktryny i orzecznictwa, praktyka nie poradziła sobie z tym specyficznym rodzajem środka odwoławczego wyłącznie w oparciu o wyjątkowo zdawkowy materiał normatywny, przez co w pracach przedstawicieli nauki procesu karnego bez wątpienia łatwiej jest znaleźć punkty sporne aniżeli zagadnienia, co do których panowałaby powszechna zgoda.

Wątpliwości wzbudziła m.in. kwestia odpowiedniego stosowania art. 437 § 1 zd. 1 K.p.k. do środków odwoławczych dotyczących uzasadnień, tzn. czy sąd odwoławczy może uchylić samo uzasadnienie i w tym zakresie przekazać sprawę do ponownego rozpoznania ${ }^{20}$, a nawet sama

20 Zob. D. Świecki, Konstrukcja.., s. 213 i cytowana tam literatura. 
forma rozstrzygnięcia, tj. czy sąd odwoławczy powinien merytorycznie zakończyć taką sprawę $\mathrm{w}$ drodze wyroku ${ }^{21} \mathrm{czy}_{\text {postanowienia }}{ }^{22}$.

Po drugie, w najbliższym czasie należy się spodziewać wzrostu spraw zainicjowanych wniesieniem tego typu środka zaskarżenia. Wynika to z wprowadzenia $\mathrm{w}$ art. 99a $\S 1$ K.p.k. obowiązku sporządzania przez sądy I instancji uzasadnień wyroków wyłącznie według ściśle określonego wzoru (formularza). Dotychczas sędziowie sprawozdawcy mieli dość znaczną, bo wyznaczoną jedynie treścią art. 424 K.p.k., swobodę w zakresie doboru metod sporządzenia uzasadnienia wyroku ${ }^{23}$. Stąd też większość kwestii przekraczających zakres przywołanego przepisu stanowiła swoiste licentia poetica konkretnego sędziego (ot choćby zastosowana kolejność rozważań), których kontrolowanie pozostawało poza zakresem kognicji sądu odwoławczego. Wraz z wejściem w życie rozporządzenia Ministra Sprawiedliwości w sprawie określenia wzorów formularzy uzasadnienia wyroku oraz sposobu ich wypełniania, swoboda ta ulegnie znacznemu ograniczeniu, jako że wzrośnie liczba koniecznych do zastosowania wzorców kontroli, co - przynajmniej na początkowym etapie „wdrażania się” przez polski wymiar sprawiedliwości do tego rozwiązania - może poskutkować wzrostem skarg na uzasadnienia wyroków.

Wprowadzając art. 443a K.p.k., przesądzono m.in. kwestię podstaw odwoławczych, odsyłając do odpowiedniego stosowania art. 438 i 440 K.p.k. Wydaje się, że rozwiązanie to w praktyce nie okaże się zbyt pomocne, ponieważ większość treści normatywnej art. 438 K.p.k. w rzeczywistości nie nada się do choćby odpowiedniego stosowania w sprawach dotyczących uzasadnień (najprawdopodobniej sądy będą się odwoływały wyłącznie do pkt 3 tego przepisu; zarzut obrazy przepisów prawa

21 Tak S. Steinborn, Glosa do uchwaty SN z dnia 20 października 1999 r., I KZP 33/99, Orzecznictwo Sądów Polskich 2000, z. 7, poz. 120, s. 409; S. Zabłocki, w: Kodeks postępowania karnego. Komentarz, t. 3, red. Z. Gostyński, R.A. Stefański, S. Zabłocki, Warszawa 2004, s. 295 .

22 D. Świecki, Zaskarżalność uzasadnienia orzeczenia karnego, Przegląd Sądowy 2009, nr 4, s. 84; uchwała SN z dnia 20 października 1999 r., I KZP 33/99, OSNKW 1999, nr 11-12, poz. 71; postanowienie SN z dnia 26 sierpnia 2004 r., I KZP 15/05, OSNwSK 2005, nr 1, poz. 2545; postanowienie SA w Katowicach z dnia 30 maja 2014 r., II AKa 129/14, KZS 2014, nr 10, poz. 86 .

${ }^{23} \mathrm{~W}$ odniesieniu do postanowień brak jest nawet takiej ogólnej normy dotyczącej wymaganych elementów jego uzasadnienia, zob. jednak postanowienie SN z dnia 15 lutego 2001 r., III KKN 595/00, KZS 2001, nr 9, poz. 11, s. 10; postanowienie SA w Krakowie z dnia 21 czerwca 2000 r., II AKz 219/00, KZS 2000, nr 6, poz. 17, s. 11. 
czy rażącej niewspółmierności kary, nawet jeżeli formalnie skierowany przeciwko uzasadnieniu, w rzeczywistości dotyczył będzie przecież raczej wyroku). Równocześnie trudno sobie wyobrazić układ procesowy, w którym uzasadnienie jawi się jako rażąco niesprawiedliwe, podczas gdy samemu orzeczeniu nie sposób zarzucić żadnego uchybienia. Warto również zauważyć, że odesłanie do art. 440 K.p.k. nakazuje przyjąć, iż sąd odwoławczy nie może się ograniczyć do rozważania zarzutów wskazanych w treści środka odwoławczego, ale obowiązany jest również z urzędu - rozstrzygnąć, czy nie istnieją podstawy do zastosowania tego przepisu. Słusznie zaniechano odesłania także do art. 439 K.p.k. Oczywiste jest, że w przypadku ziszczenia się którejkolwiek ze wskazanych w tym przepisie przesłanek, wadliwość dotyczyć będzie zawsze również samego orzeczenia.

Nowelizacja rozwiązała również zarysowany wyżej problem możliwych rodzajów i formy rozstrzygnięć sądu II instancji. Przesądzono, że sąd odwoławczy władny jest wydać jedynie orzeczenie o utrzymaniu w mocy lub zmianie zaskarżonego uzasadnienia (art. 443a § 4 K.p.k.), jak i że rozstrzygnięcie takie powinno każdorazowo przybrać formę postanowienia. To ostatnie wynika z przyjęcia, że właściwym środkiem odwoławczym od uzasadnienia orzeczenia jest zażalenie, chyba że chodzi o sytuacje, w których skarżący wniósł również apelację (art. 443a § 4 K.p.k.). Zdecydowano się zatem na wprowadzenie kolejnego już - obok znanego wcześniej z art. 626 § 3 K.p.k. oraz art. 18 ustawy z dnia 23 czerwca 1973 r. o opłatach w sprawach karnych ${ }^{24}$ - przypadku, w którym forma środka odwoławczego zależna jest od tego, czy skarżący wniósł również dalej idący środek.

\section{Przyczyny oddalenia wniosku dowodowego}

W wyniku wejścia w życie nowelizacji z 19 lipca 2019 r., w art. 452 $\S 2$ pkt 2 K.p.k. sformułowano kolejną przesłankę oddalenia wniosku dowodowego w instancji odwoławczej. Przepis ten nie wprowadza do polskiego procesu karnego żadnego novum, ponieważ przedmiotowy zakres jego zastosowania w zasadzie odpowiada treści art. 427 § 3 K.p.k.,

24 Dz. U. z 1983 r. Nr 49, poz. 223 z późn. zm. 
statuującemu prekluzję dowodową w postępowaniu odwoławczym ${ }^{25}$. Regulacje te różnią się właściwie jedynie co do adresata. Ostatni z nich został skierowany bezpośrednio do odwołującego się, któremu zakazano wskazywania w treści środka odwoławczego ${ }^{26}$ nowych faktów lub dowodów, które mógł powołać już na etapie postępowania pierwszoinstancyjnego, podczas gdy art. $452 \S 2$ pkt 2 K.p.k. adresowany jest do sądu i ma pełnić rolę przepisu szczególnego względem art. 170 § 1 K.p.k.

Zdecydowanie bardziej istotna wydaje się $\mathrm{w}$ związku $\mathrm{z}$ tym treść art. 452 § 3 K.p.k., zgodnie z którym wniosku dowodowego nie można oddalić na podstawie nowododanej przesłanki, jeżeli okoliczność, która ma być udowodniona, w granicach rozpoznania sprawy przez sąd odwoławczy, ma istotne znaczenie dla ustalenia:

1) czy został popełniony czyn zabroniony;

2) czy czyn ten stanowi przestępstwo, a jeśli tak, to jakie;

3) czy czyn ten został popełniony w warunkach powrotu do przestępstwa lub

4) czy zachodzą warunki do orzeczenia środka zabezpieczającego $\mathrm{w}$ postaci pobytu $\mathrm{w}$ zakładzie psychiatrycznym.

Warto zauważyć, że zakaz przewidziany w art. 427 § 3 K.p.k. nie wskazuje okoliczności wyłączonych spod zakresu jego zastosowania, w związku z czym należy uznać, że począwszy od dnia wejścia w życie omawianej nowelizacji, dotychczasowy zasięg działania prekluzji dowodowej zostanie znacząco ograniczony (wyłącznie do okoliczności niewchodzących w skład przytoczonego katalogu). Z kolei te, które dotyczą kwestii expressis verbis wymienionych $\mathrm{w}$ tym przepisie, a contrario mogą być przez skarżącego przywołane w postępowaniu odwoławczym nawet wtedy, jeśli mógł to uczynić już przed sądem I instancji.

Co zaś tyczy się okoliczności objętych zakresem art. 452 § 3 K.p.k. (tożsamych ze wskazanymi w art. 170 § 1a oraz w art. 427 § 3a in fine K.p.k.), ich dobór należy uznać za zbyt sztywny, a w konsekwencji nie do końca

25 Por. S. Zabłocki, Między reformatoryjnościa a kasatoryjnościa, między apelacyjnościa a rewizyjnościa - ku jakiemu modelowi zmierza postępowanie odwoławcze po zmianach kodeksowych z lat 2013-2015, w: Obrońca i petnomocnik w procesie karnym po 1 lipca 2015 r. Przewodnik po zmianach, red. P. Wiliński, Warszawa 2015, s. 424.

${ }^{26}$ Jak również $\mathrm{w}$ treści wniosku dowodowego złożonego już po wniesieniu środka odwoławczego (tak S. Zabłocki, Między..., s. 424; odmiennie S. Steinborn, Postępowanie dowodowe w instancji apelacyjnej w świetle nowelizacji kodeksu postępowania karnego, Prokuratura i Prawo 2015, nr 1, s. 155-156; szerzej D. Świecki, Konstrukcja..., s. 268). 
trafny. Bez wątpienia projektodawca chciał w sposób możliwie najbardziej syntetyczny wskazać najistotniejsze kwestie, których swobodne dowodzenie nie powinno być ograniczone na żadnym etapie procesu aż do jego prawomocnego zakończenia, jednakże w konkretnym stanie faktycznym waga tych okoliczności może się prezentować różnie w zestawieniu z tymi, które z kolei nie są objęte hipotezą przywołanego przepisu.

Przykładowo, skarżący wykazujący bierną postawę w toku postępowania głównego będzie mógł w postępowaniu odwoławczym dowodzić, że jedno z przypisanych mu przestępstw (zniesławienie) nie zostało popełnione za pomocą środków masowego przekazu (a zatem że stanowi inne przestępstwo), ale już nie tego, że zagrożone przepadkiem w związ$\mathrm{ku} \mathrm{z}$ popełnieniem innego przestępstwa i warte setki milionów złotych mienie, objęte przez niego we władanie w okresie 5 lat przed tym czynem, nie stanowi korzyści uzyskanej w wyniku jego popełnienia. Innymi słowy, nadmierna kazuistyka art. 452 § 3 K.p.k. może prowadzić do wypaczenia jego ratio legis, którym miało być przecież wyłączenie prekluzji dowodowej w odniesieniu do kwestii najważniejszych dla danego postępowania.

Skoro ustawodawca chciał złagodzić obowiązujący w postępowaniu odwoławczym system prekluzji (niekiedy zwany również zasadą ewentualności), być może właściwszym rozwiązaniem byłoby zastąpienie go innym z możliwych systemów koncentracji materiału procesowego. Chodzi tu o znany m.in. z postępowania cywilnego system dyskrecjonalnej władzy sędziego, w którym prawodawca a priori nie określa precyzyjnie terminów, po upływie których gromadzenie materiału procesowego jest już niedopuszczalne, ale o ramach czasowych gromadzenia tego materiału każdorazowo decyduje sąd, mogący w realiach konkretnego stanu faktycznego najlepiej ocenić wagę danej okoliczności dla przebiegu postępowania $^{27}$. Zastosowanie systemu dyskrecjonalnej władzy sędziego pozwoliłoby z pewnością na zastąpienie sztywnego i kazuistycznego wyliczenia "okoliczności najistotniejszych" stosownym zwrotem niedookreślonym, którego wypełnienie treścią (odkodowanie zbioru tychże

27 Zob. W. Broniewicz, A. Marciniak, I. Kunicki, Postępowanie cywilne w zarysie, Warszawa 2016, s. 77-79, por. również art. 381 ustawy z dnia 17 listopada 1964 r. - Kodeks postępowania cywilnego (Dz. U. z 2019 r. poz. 1460 i 1469), zgodnie z którym „Sąd drugiej instancji może [a zatem, inaczej niż na gruncie art. $452 \S 2$ pkt 2 K.p.k., nie musi - B.Ł.] pominąć nowe fakty i dowody, jeżeli strona mogła je powołać w postępowaniu przed sądem pierwszej instancji, chyba że potrzeba powołania się na nie wynikła później”. 
okoliczności) nastąpiłoby dopiero $\mathrm{w}$ orzecznictwie sądowym ${ }^{28}$, niemniej zajęcie kategorycznego stanowiska $\mathrm{w}$ tej kwestii wydaje się na być tym etapie zdecydowanie przedwczesne.

Jedynie na marginesie warto $\mathrm{w}$ tym miejscu zauważyć, że $\mathrm{w}$ praktyce sposobem na obejście omawianego rygoryzmu może się okazać składanie przez strony wniosków w trybie art. 9 § 2 K.p.k., w treści których zasugerują one sądowi, iż ze względu na wagę konkretnej okoliczności powinien dopuścić dany dowód z urzędu.

\section{Reguły ne peius}

Ustawodawca zdecydował się również na przemodelowanie katalogu reguł ne peius, usuwając z niego przepisy dotychczas zabraniające sądowi ad quem:

1) skazać oskarżonego, w stosunku do którego w postępowaniu przed sądem I instancji warunkowo umorzono postępowanie (art. $454 \S 1$ K.p.k.) oraz

2) zaostrzyć karę wymierzoną w wyroku sądu I instancji poprzez jej zmianę na karę dożywotniego pozbawienia wolności (art. 454 $\S 3$ K.p.k.).

W odniesieniu do drugiego z tych zakazów projektodawca przyjął, że choć regulacja ta stanowiła dodatkową gwarancję dostępu do sądu II instancji, to jednak na gruncie konstytucyjnym, jak i konwencyjnym nie była gwarancją konieczną ${ }^{29}$. Tym samym, korzystając ze swobody wyznaczonej mu treścią norm wyższego rzędu, uznał, iż ustawową ochroną należy objąć wyłącznie dwuinstancyjność w znaczeniu formalnym, nie zaś chronioną dotychczas na gruncie art. 454 § 3 K.p.k. dwuinstancyjność $\mathrm{w}$ znaczeniu materialnym (tzw. dwuinstancyjność skazania) ${ }^{30}$. Wydaje się, że zmiana ta nie wymaga szerszego komentarza, w związku z czym

28 Warto podkreślić, że odmienność środków, jakimi posługują się oba systemy koncentracji materiału procesowego, nie stoi na przeszkodzie, aby w konkretnie obowiązujących ustawach procesowych występowały obok siebie elementy zarówno jednego, jak i drugiego systemu (tak trafnie H. Mądrzak, w: H. Mądrzak, E. Marszałkowska-Krześ, Postępowanie cywilne, red. H. Mądrzak, Warszawa 2003, s. 64).

29 Uzasadnienie..., s. 64-65.

30 Wyrok SA w Łodzi z dnia 18 lutego 2014 r., II AKa 3/14, LEX nr 1461064. 
w toku dalszych wywodów skupiono się wyłącznie na modyfikacji pierwszego z wymienionych zakazów.

Zgodnie $\mathrm{z}$ art. 14 ust. 5 MPPOiP ${ }^{31}$ każdy skazany za przestępstwo ma prawo do odwołania się do sądu wyższej instancji w celu ponownego rozpatrzenia orzeczenia o winie i karze zgodnie $z$ ustawą. W piśmiennictwie przyjmuje się, że przepis ten powinien być interpretowany w ten sposób, że uprawnienie do zaskarżenia wyroku skazującego dotyczy nie tylko orzeczenia wydanego w I instancji, ale również wyroku sądu II instancji, w którym po raz pierwszy skazano oskarżonego ${ }^{32}$. Projektodawca uznał, że wyrok sądu odwoławczego skazujący osobę, w stosunku do której $\mathrm{w}$ postępowaniu pierwszoinstancyjnym warunkowo umorzono postępowanie, nie mieści się w zakresie pojęcia „wyroku sądu II instancji, w którym po raz pierwszy skazano oskarżonego", w związku z czym uchylił zakaz ne peius w odniesieniu do tego rodzaju orzeczeń.

Zmiana ta opiera się na błędnym (choć niestety zadekretowanym w art. 342 § 1 K.p.k.) przeświadczeniu, że warunkowe umorzenie wymaga przypisania sprawcy konkretnego czynu oraz stwierdzenia jego winy ${ }^{33}$. Należy się jednak zastanowić, czym w rzeczywistości jest owo „przypisanie czynu" i czy pod pojęciem tym rzeczywiście mieści się również wyrok warunkowo umarzający.

Wbrew przeważającemu stanowisku doktryny ${ }^{34}$ należy stwierdzić, że wyrok taki nie obala konstytucyjnego domniemania niewinności. Czym innym jest bowiem stanowiące materialnoprawną przesłankę zastosowania tego środka probacyjnego wewnętrzne (subiektywne) przekonanie sędziego o winie oskarżonego, a czym innym przypisanie mu jej $\mathrm{w}$ znaczeniu instytucjonalnym (tj. poprzez użycie przez sąd $\mathrm{w}$ wyroku

31 Międzynarodowy Pakt Praw Obywatelskich i Politycznych otwarty do podpisu w Nowym Jorku dnia 19 grudnia 1966 r. (Dz. U. z 1977 r. Nr 38, poz. 167).

${ }_{32}$ M. Wąsek-Wiaderek, Wybrane aspekty postępowania odwoławczego w procesie karnym po 1 lipca 2015 r. w świetle standardów międzynarodowych, w: Postępowanie odwoławcze w procesie karnym - u progu nowych wyzwań, red. S. Steinborn, Warszawa 2016, s. 157; D. Świecki, Konstrukcja..., s. 176. Pogląd ten znalazł aprobatę również w treści uzasadnienia projektu nowelizacji (Uzasadnienie..., s. 64).

$33 \mathrm{Za}$ usunięciem warunkowego umorzenia postępowania $\mathrm{z}$ katalogu rozstrzygnięć wymienionych w art. 454 § 1 Kp.k. opowiedział się z kolei M. Fingas, Orzekanie..., s. 268 i nast.

${ }^{34}$ Zamiast wielu zob. B. Kunicka-Michalska, Warunkowe umorzenie postępowania karnego, w: Kary i inne środki reakcji prawnokarnej, red. M. Melezini, Warszawa 2016, s. 1021-1025 i cytowana tam literatura. 
skazującym formuły „uznaje za winnego") ${ }^{35}$. Prawdą jest, że orzeczenie o warunkowym umorzeniu opiera się na ustaleniu winy sprawcy czynu zabronionego, a nawet na rozstrzygnięciu o jej stopniu, jednakże nie jest to ustalenie (stwierdzenie) w sposób instytucjonalny, o którym mowa w art. 42 ust. 3 Konstytucji RP ${ }^{36}$, przez co nie wiąże się z jej przypisaniem. Reguły ne peius muszą zaś chronić każdego, kto w I instancji nie został uznany winnym, a zatem czyjego wina nie została stwierdzona, a następnie przypisana mu właśnie w sposób instytucjonalny.

Przeciwny pogląd z jednej strony prowadzi do przyjęcia karkołomnej konstrukcji „skazania na czas pomyślnego upływu okresu próby”, po którym (oraz dodatkowych 6 miesiącach) warunkowe umorzenie, jakoby mające charakter skazujący, staje się bezwarunkowe ${ }^{37}$, a z drugiej oznacza, że $\mathrm{w}$ razie podjęcia postępowania oskarżonego powinno się traktować w zasadzie jak skazanego, skoro kwestia jego winy została już prawomocnie przesądzona, zaś ponowne prowadzenie postępowania wynika jedynie z jego nagannego zachowania w okresie próby (z założenia podjęcie postępowania ma zatem służyć raczej pogorszeniu jego „wyjściowej” sytuacji).

Wsparciem dla przedstawionej tezy jest również fakt, że zawarte w wyroku skazującym rozstrzygnięcie o winie oskarżonego ma charakter konstytutywny ${ }^{38}$, a zatem - interpretując użyte w przywołanym wyżej przepisie konstytucyjnym wyrażenie „wina stwierdzona” w sposób możliwie najbardziej gwarancyjny - należy przyjąć, że sąd karny nie tyle

35 Podobnie M. Cieślak, którego zdaniem wyrok taki nie zawiera orzeczenia o winie, mimo że podstawę jego wydania stanowi „dowodowe ustalenie winy” (M. Cieślak, Materialnoprawne oblicze warunkowego umorzenia, Państwo i Prawo 1971, z. 3 s. 617-618), por. wyrok TK z dnia 16 maja 2000 r., P 1/99, OTK 2000, nr 4, poz. 111.

36 Ustawa z dnia 2 kwietnia 1997 r. - Konstytucja Rzeczypospolitej Polskiej (Dz. U. Nr 78, poz. 483; 2001 r. Nr 28, poz. 319; 2006 r. Nr 200, poz. 1471 oraz 2009 r. Nr 114, poz. 946). Za nietrafny należy uznać argument zasadzający się na nieużyciu przez ustrojodawcę w tym przepisie słowa "skazującym” (tak T. Kozioł, Warunkowe umorzenie postępowania karnego, Warszawa 2009, s. 37). Z uwagi na specyfikę ustawy zasadniczej, w tym zwłaszcza na stopień jej ogólności (zachowany wszak kosztem precyzji językowej), z samego faktu zaniechania użycia tego słowa nie należy wyprowadzać tak daleko idących wniosków.

37 Tak S. Hypś, w: Kodeks karny. Komentarz, red. A. Grześkowiak, K. Wiak, Warszawa 2019, Nb. 4 do art. 66.

${ }^{38} \mathrm{~W}$ kwestii sporu co do konstytutywnego charakteru orzeczeń sądów karnych zob. w szczególności P. Hofmański, Samodzielność jurysdykcyjna sądu karnego, Katowice 1988, s. 109. 
„odkrywa" (w sposób deklaratoryjny) winę istniejącą po stronie sprawcy już w momencie popełnienia przestępstwa, co "nakłada ją” na niego ze skutkiem ex nunc ${ }^{39}$. Tymczasem w sentencji orzeczenia o warunkowym umorzeniu postępowania brak jest takiego rozstrzygnięcia o winie, tzn. odrębnego punktu wyroku, w którym uznaje się oskarżonego za winnego zarzuconego mu czynu. Kwestia sprawstwa i winy zostaje przesądzona dopiero w uzasadnieniu takiego orzeczenia, w związku z czym nie sposób przyjąć, że wyrok warunkowo umarzający postępowanie przypisuje komukolwiek winę (lub czyn) w przyjętym tu rozumieniu.

Argumentem przemawiającym za koniecznością utrzymania omawianego zakazu nie może być $\mathrm{z}$ kolei jego obowiązywanie w stosunku do osób, wobec których w I instancji umorzono postępowanie. Należy uznać, że instytucja warunkowego umorzenia postępowania stanowi $\mathrm{w}$ istocie swoistą postać zawieszenia postępowania na okres próby, która - rzecz jasna poza nazwą - nie wykazuje zbyt wielu podobieństw do "zwykłego" umorzenia postępowania, przez co na gruncie prawa procesowego nie powinno się ich traktować łącznie, w tym również w kontekście art. 454 § 1 K.p.k.

Jedynie na marginesie warto zauważyć, że uzasadnieniem dla ograniczania gwarancji procesowych oskarżonego do niezbędnego minimum, wynikającego z norm rangi konstytucyjnej i konwencyjnej, nie powinno być samo dążenie ustawodawcy do maksymalizacji sprawności postępowania. Należy mieć na uwadze fakt, że w przypadku uchylenia wyroku skazującego przez sąd odwoławczy ze względu na potrzebę rozważenia w postępowaniu ponownym orzeczenia kary dożywotniego pozbawienia wolności nie jest przecież konieczne powtarzanie całego przewodu od nowa, a tym samym kolejny wieloletni proces ${ }^{40}$. Stąd też sam fakt istnienia określonych zakazów ne peius nie musi być każdorazowo postrzegany jako osłabienie wyrażonej w art. $2 \S 1$ pkt 4 K.p.k. dyrektywy rozstrzygnięcia sprawy w rozsądnym terminie. Innymi słowy, postulat usprawnienia

39 Podobnie S. Steinborn, Prawomocność części orzeczenia w procesie karnym, Warszawa 2011, s. 175-176. Warto jednak odnotować, że autor ten uznaje wyrok warunkowo umarzający za obalający domniemanie niewinności (s. 175 i 495).

40 Trafnie zwrócono na to uwagę w stanowisku Sekcji Prawa i Postępowania Karnego przy Okręgowej Radzie Adwokackiej w Warszawie do projektu zmian kodeksu postępowania karnego z dnia 4 grudnia 2018 roku, https:/ / legislacja.rcl.gov.pl/docs/ / 2/1231880 6/12554727/12554730/dokument377909.pdf, s. 9-10 [dostęp: 25.07.2019 r.]. 
procesu nie musi iść $\mathrm{w}$ parze $\mathrm{z}$ aż tak zdecydowanym ograniczaniem praw i wolności oskarżonego.

\section{Zakończenie}

Całościowa ocena nowelizacji z 19 lipca 2019 r. nie jest możliwa w ramach artykułu, ponieważ jej rozmiar i szczegółowość pozwalają co najwyżej na ocenę pojedynczych, konkretnych rozwiązań. Często jednak i to zadanie, przynajmniej do czasu zapoznania się ze sposobem, w jaki nowe przepisy będą stosowane w praktyce orzeczniczej sądów karnych, wydaje się być nad wyraz skomplikowane. Do głównych wad omówionych w tekście konstrukcji z pewnością należą: niezbyt czytelne wprowadzanie reguł pod postacią wyjątków (art. 427 § 3a K.p.k.), podważanie istoty norm prawa materialnego (art. 438 pkt 1a K.p.k.), dość bezrefleksyjne ograniczanie uprawnień procesowych stron do minimalnego standardu wyznaczonego normami wyższego rzędu (reguły ne peius) i wreszcie wątpliwa praktyczna wartość niektórych z proponowanych regulacji (sztywny katalog z art. 452 $\S 3$ K.p.k. oraz odesłanie do stosowania art. 438 i 440 K.p.k. w przypadku zaskarżenia uzasadnienia).

Już teraz jednak można pokusić się o ogólne spostrzeżenie, że - bez względu na trafność wprowadzenia opisanych wyżej rozwiązań - dalsza polaryzacja poszczególnych etapów postępowania jurysdykcyjnego, objawiająca się z jednej strony wzmacnianiem inkwizycyjności postępowania pierwszoinstancyjnego, a $z$ drugiej kontradyktoryjności postępowania odwoławczego, może doprowadzić do zaburzenia wewnętrznej spójności polskiego procesu karnego ${ }^{41}$. Tym samym należy liczyć na to, że ustawodawca zdecyduje się w końcu na ostateczne określenie, w którym kierunku powinien zmierzać model postępowania sądowego.

41 Dotychczas etapami procesu przeciwstawianymi sobie pod względem ich formy były raczej postępowanie przygotowawcze oraz postępowanie jurysdykcyjne, nie zaś poszczególne odcinki tego ostatniego; zob. J. Skorupka, w: Proces..., s. 57. 


\section{Bibliografia}

Bator A., w: Wprowadzenie do nauk prawnych. Leksykon tematyczny, red. A. Bator, Warszawa 2008.

Broniewicz W., Marciniak A., Kunicki I., Postepowanie cywilne w zarysie, Warszawa 2016.

Cieślak M., Materialnoprawne oblicze warunkowego umorzenia, Państwo i Prawo 1971, z. 3-4.

Cieślak M., Polska procedura karna. Podstawowe założenia teoretyczne, Warszawa 1973.

Fingas M., Orzekanie reformatoryjne w instancji odwoławczej w polskim procesie karnym, Warszawa 2016.

Hofmański P., Samodzielność jurysdykcyjna sądu karnego, Katowice 1988.

Hypś S., w: Kodeks karny. Komentarz, red. A. Grześkowiak, K. Wiak, Warszawa 2019.

Kozioł T., Warunkowe umorzenie postępowania karnego, Warszawa 2009.

Kunicka-Michalska B., Warunkowe umorzenie postępowania karnego, w: Kary i inne środki reakcji prawnokarnej, red. M. Melezini, Warszawa 2016.

Machnikowski P., w: Kodeks cywilny. Komentarz, red. E. Gniewek, Warszawa 2006.

Matras J., w: Kodeks postepowania karnego. Komentarz, red. K. Dudka, Warszawa 2018.

Mądrzak H., w: H. Mądrzak, E. Marszałkowska-Krześ, Postępowanie cywilne, red. H. Mądrzak, Warszawa 2003.

Skorupka J., w: Ciężar dowodu i obowiązek dowodzenia w procesie karnym, red. W. Jasiński, J. Skorupka, Warszawa 2017.

Skorupka J., w: Proces karny, red. J. Skorupka, Warszawa 2018.

Stefański R.A., Wykładnia przepisów prawa karnego, w: Źródła prawa karnego, red. T. Bojarski, Warszawa 2011.

Steinborn S., Glosa do uchwaty SN z dnia 20 października 1999 r., I KZP 33/99, Orzecznictwo Sądów Polskich 2000, z. 7-8, poz. 120.

Steinborn S., Prawomocność części orzeczenia w procesie karnym, Warszawa 2011.

Steinborn S., Postępowanie dowodowe w instancji apelacyjnej w świetle nowelizacji kodeksu postępowania karnego, Prokuratura i Prawo 2015, nr 1-2.

Świecki D., Zaskarżalność uzasadnienia orzeczenia karnego, Przegląd Sądowy 2009, nr 4.

Świecki D., Konstrukcja apelacji jako środka odwoławczego w procesie karnym, Warszawa 2018.

Wąsek-Wiaderek M., Wybrane aspekty postepowania odwoławczego w procesie karnym po 1 lipca 2015 r. w świetle standardów międzynarodowych, w: Postępowanie 
odwoławcze w procesie karnym - u progu nowych wyzwań, red. S. Steinborn, Warszawa 2016.

Zabłocki S., w: Kodeks postepowania karnego. Komentarz, t. 3, red. Z. Gostyński, R.A. Stefański, S. Zabłocki, Warszawa 2004.

Zabłocki S., Między reformatoryjnościa a kasatoryjnościa, między apelacyjnościa a rewizyjnościa - ku jakiemu modelowi zmierza postępowanie odwoławcze po zmianach kodeksowych z lat 2013-2015, w: Obrońca i petnomocnik w procesie karnym po 1 lipca 2015 r. Przewodnik po zmianach, red. P. Wiliński, Warszawa 2015.

\section{Streszczenie}

19 lipca 2019 r. uchwalono nowelizację Kodeksu postępowania karnego, która w znaczący sposób przebudowała dotychczasowy kształt postępowania odwoławczego w sprawach karnych. Celem tej pracy jest analiza niektórych z wprowadzonych tą nowelizacją zmian. Szczegółowe rozważania dotyczą modyfikacji w zakresie zarzutów możliwych do podniesienia w treści środka odwoławczego, problematyki zaskarżania uzasadnień, a także zmian $\mathrm{w}$ zakresie podstaw oddalenia wniosku dowodowego oraz redukcji części reguł ne peius.

Słowa kluczowe: postępowanie odwoławcze, podstawy odwoławcze, zażalenie na uzasadnienie, reguły ne peius, proces karny

\section{APPEAL PROCEEDINGS IN CRIMINAL CASES ON THE BASIS OF THE AMENDMENT OF 19 JULY 2019 - SELECTED ISSUES}

\section{Sum mary}

On 19 July 2019, an amendment to the Polish Code of Criminal Procedure was passed, which significantly changed the current form of appeal proceedings in criminal cases. The aim of this work is to analyse some of the changes introduced by this amendment. The detailed considerations relate to changes of the objections that can be raised in the content of the appeal measure, the issue of appealing against a statement of reasons, as well as changes in the grounds for dismissal of an evidentiary motion and the reduction of part of the ne peius rules.

Key words: appeal proceedings, grounds for an appeal, interlocutory appeal against a statement of reasons, ne peius rules, criminal proceedings 


\section{АПЕЛЛЯЦИОННОЕ ПРОИЗВОДСТВО В УГОЛОВНОМ ПРОЦЕССЕ НА ОСНОВАНИИ ВНЕСЕННЫХ ИЗМЕНЕНИЙ ОТ 19 ИЮЛЯ 2019 Г. - ИЗБРАННЫЕ ВОПРОСЫ}

\section{Резюме}

19 июля 2019 года были внесены изменения в Уголовно-процессуальный кодекс, существенно изменившие нынешнюю форму апелляционного производства по уголовным делам. Цель данной работы - проанализировать некоторые изменения, внесенные этой поправкой. Подробные рассуждения касаются изменений в объеме обвинения, возможных для поднятия в содержании апелляционной жалобы, проблематики оспаривания мотивировочной части судебного решения, а также изменений в отношении оснований отклонения ходатайства о доказательствах и сокращения части правил пе peius.

Ключевые слова: производство по обжалованию судебных решений, основания для обжалования, обжалование мотивировочной части судебного решения, правила пе peius, уголовный процесс 
